\title{
Adatok Barcs és környéke középkori vaskohászatához
}

\author{
1RÓZSÁS MÁRTON \\ ${ }^{1} \mathrm{H}-7570$ Barcs, Krénusz J. u. 16., e-mail: rozsas.barcs@freemail.hu
}

RózsÁs, M.: Medieval iron smelting at Barcs and in its broader area

Abstract: The area along the County Somogy section of the River Drava was an archaeological blank spot until recent decades. Several previously unknown archaeological sites from the Neolithic to the Early Modern Age were identified during the field surveys conducted by the author since the 1970s. Described and discussed here are a few sites associated with medieval iron smelting dating from the ninth to the fifteenth century.

Keywords: early Medieval, Drava region, iron, slag, meadow-ore

\section{Bevezetés}

Somogy megye, ezen belül Belső-Somogy és a Dráva menti régió, a régészeti kutatások szempontjából hosszú évtizedekig az ország fehér foltjának számított. A Dráva mente felfedezését nemcsak a szakemberek hiánya, hanem a sokáig élő határsáv is akadályozta. Az 1970-es években, a frissen végzett szakemberek számára azonban egy-egy szakdolgozat elkészítésének erejéig már igen hálás terepnek bizonyult, éppen a terepmunka által feltárt új adatoknak, és azok közreadásának köszönhetően. Mint a régészet és a helytörténet iránt aktívan érdeklődő ember, viszonylag korán, az 1970-es évek közepén kezdtem el terepbejárásaimat Barcs környékén. Később, az 1980-as években, a megyei múzeumi szervezet régészei közül többen igen pozitívan viszonyultak munkámhoz, köztük volt dr. Költő László, az akkori régészeti osztályvezető is. Tanácsokkal látott el, segített, ha kellett, mindig számíthattam rá és csapatára. ${ }^{1}$ 1987-ben a barcsi Dráva Múzeumhoz kerültem, ettől kezdve a terepbejárások hivatalos formát öltöttek. ${ }^{2}$

Közleményemben néhány olyan barcsi, és Barcs környéki lelőhelyre kívánom felhívni a figyelmet, melyeken vaskohászatra utaló leletek is előkerültek, de ezek eddig nem kerültek regisztrációra, közlésre. A terepbejárások során gyűjtött leletanyag azonban - véleményem szerint - alkalmas arra, hogy néhány óvatos megállapítást tehessek e kevéssé ismert területen egykor folyt vaskohászatot, vasfeldolgozást illetően. Hangsúlyoznom kell, hogy jelen munka terepbejárásokra, szórványos leletekre épül, így csupán a téma topográfiai megközelítésére szorítkozhatok, meghagyva a részletesebb, szakszerü feldolgozás lehetőségét az archeometallurgiával foglalkozó szakemberek számára. Sajnos a lelőhelyek egy része ma már nem kutatható, részben az erdősítések, részben a múvelési ágak változásai miatt.

Az iparrégészeti kataszterben legközelebbi lelőhelyként a Barcstól északkeletre, 44 kilométerre elhelyezkedő Ötvöskónyi szerepel. ${ }^{3}$ Újabban, a környéken folyó mikrorégiós és topográfiai kutatások nyomán azonban egyre szélesedik az ismeretanyag a Dráva mente középkori vaskohászatának történetére és emlékanyagára vonatkozóan. ${ }^{4}$

A tárgyalt kora középkori lelőhelyek kora - a más telepek és kohótelepekásatásai során előkerült kora középkori anyaggal összevetve - a késő avar kort követő időszakra, a 9-10. századra tehető, míg a középkori leleteket a 14-15. századra keltezhetjük.

A most közölt lelőhelyek és leletek mennyiségileg ugyan nem számottevőek, mégis megítélésem szerint újabb apró, de fontos adatot jelenthetnek a Dráva menti középkori vaskohászat megismeréséhez.

\footnotetext{
Jelen kis írásommal tisztelgek a 70 éves Költő László előtt, akihez három évtizedes ismeretség és barátság füz.

NÉMETH 2010, 44.

GöMörI 2000a, 23 2/b. kép

4 Utalnék itt Zatykó Csilla Berzence környéki tájrégészeti kutatására, vagy Jankovich-Bésán Dénes által vezetett Dráva menti topográfiai munkákra. KovácS Et AL. 2014, 155-168; FeKETE et AL. 2005, 103-106, 114-116.
} 


\section{Lelöhelyek és leletanyag}

\section{Barcs-Tarcsa-puszta, Kereszti-dülö}

A lelőhely Barcstól északnyugatra, a már nem létező Tarcsa-puszta helyétől délre mintegy 500 méterre, a Dráva egykori kanyarulata mentén helyezkedik el. Már a terepbejárások során nyilvánvalóvá vált, hogy a telepen vasolvasztással is foglalkoztak, erre utalt a felszínen heverő nagyszámú vassalak darab. ${ }^{5} 2004$ júliusában nyílt lehetőség egy kisebb szondázásra, melyet a Dráva Múzeum végzett, Költő László szakmai felügyelete mellett. A munka során kiderült, hogy a régóta folyó intenzív mezőgazdasági múvelés, különösen az altalajlazító használata a lelőhelyet súlyosan károsította, gyakorlatilag felaprította. Mindezek ellenére az előkerült leletanyag kétségtelenné tette, hogy a lelőhelyen vaskohászati tevékenység folyt. Erre nemcsak a jelentős mennyiségú vassalak, hanem fúvócsövek töredékei és mellfalazatok maradványai is egyértelműen utaltak. Sem mühelygödörre utaló nyomot, sem a kohók szerkezetére vagy típusára utaló leletet nem találtunk, így azt nem sikerült tisztázni, hogy itt voltak-e a kohók, vagy csupán a salak/törmelék lerakó hely került elő.

Mivel a művelt réteg alatti, salakot tartalmazó talajt erősen összetömörödött, szürkés színú iszap alkotta, lehet, hogy a Dráva áradása is elöntötte egykor a területet. A kohók(?) közelében nagyon kevés kora középkori kerámia és egyéb lelet került elő, viszont a műhelytől északra (200 méter), egy kis kiemelkedésen megtalálhatók a település nyomai, több ponton koncentrálódó apró kerámiatöredékek formájában. A telepet a kohók helyétől egy sekély, ma már részben feltöltődött vízmosás választja el (1.ábra). ${ }^{6}$

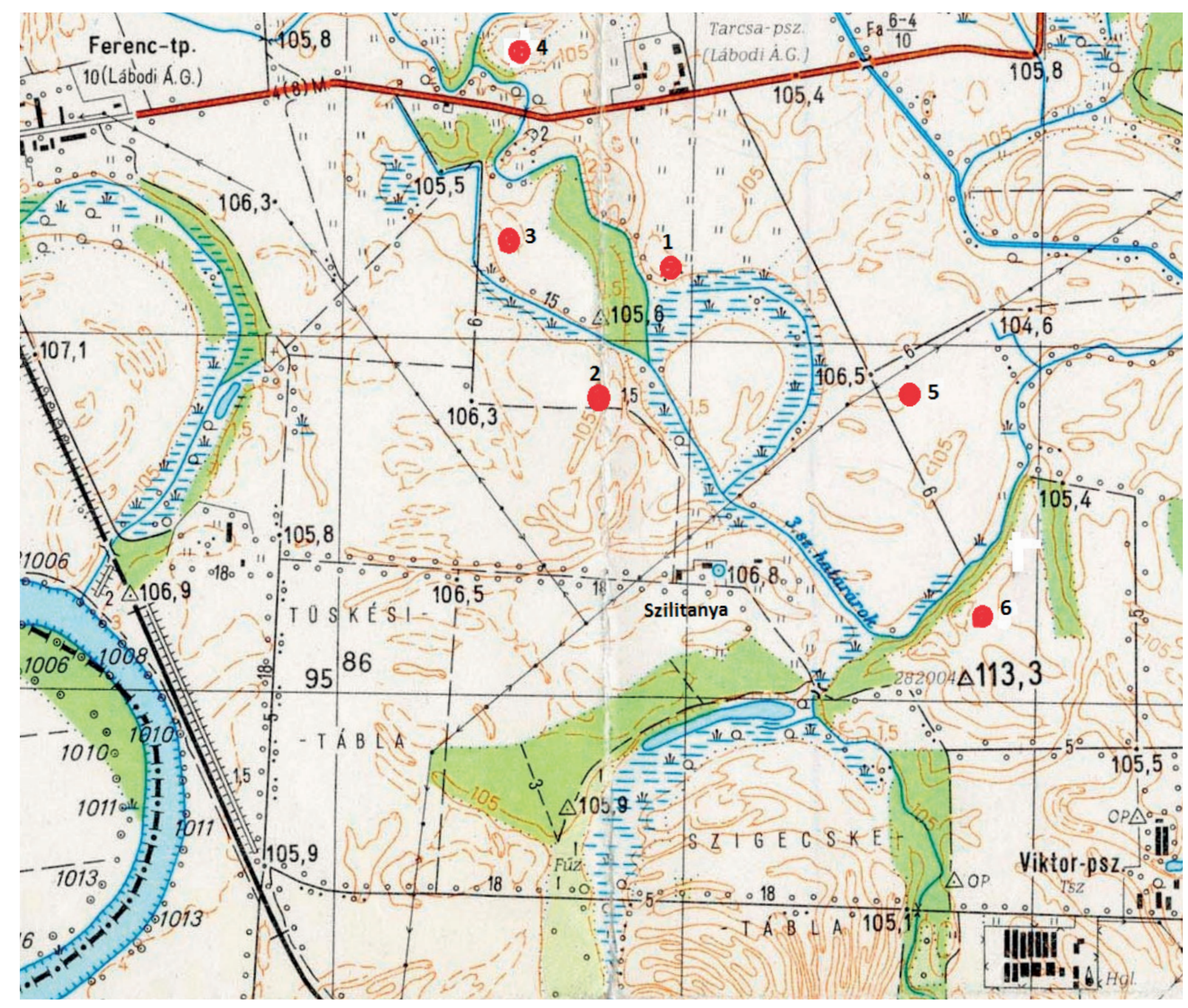

1.ábra. Barcs lelöhelyei

5 Dráva Múzeum Adattára (továbbiakban: DMA) 1041-96. Rózsás Márton jelentése. A leletanyag a Dráva Közérdekủ Muzeális Kiállítóhely (korábban Dráva Múzeum) gyűjteményében található. (továbbiakban: DKMK).

6 E népesség temetőjének részletét a közeli Puszta Barcs lelőhelyen 1988-ban tárta fel Honti Szilvia. DMA 1049-97; Leletanyag: DKMK 


\section{Barcs-Tüskési-tábla}

A Kereszti-dűlő lelőhelytől délnyugatra (kb. 400 méter), a holtág másik oldalán egy, a terepszintből alig kiemelkedő lapos földnyelven, kis területen (50×30 méter) sok vassalak darab és apró kerámiatöredék gyűjthető a felszínen. A hullámvonal köteges kerámiatöredékek alapján ennek a kis telepnek (műhely?) a korát a kora középkorra tehetjük.7 Összetartozása az előző lelőhellyel nem zárható ki teljes bizonyossággal, bár a köztes terület teljesen leletmentes. A holtág valaha nyilván élő víz lehetett, ami a közvetlen kapcsolat szempontjából komoly akadályt jelenthetett volna. Valószínủbb, hogy a lelőhely önálló, más idő intervallumban használt, rövid ideig élő kis mühely-telep lehetett.

\section{Barcs-Tüskés, 31/8. tábla}

A Tüskési-tábla lelőhelytől északnyugatra (kb. 400 méter), az egykori Dráva-ágak által közrefogott szigeten nagyon halvány kora középkori telepnyomok, hullámvonal köteges cserepekkel, kevés vassalakkal. Ugyanitt néhány darab késő vaskori/kelta grafitos cserép is előfordult. ${ }^{8}$

\section{Barcs-Tarcsa-puszta}

A Kereszti-dűlő lelőhelytől északnyugatra (700 méter), a holtág melletti beszögellésben, egy alig kiemelkedő földnyelv déli peremén nagyon szórványosan apró vassalakot és kerámiatöredékeket gyűjtöttem. ${ }^{9}$

\section{Barcs-Perdély}

Puszta Barcsról Tarcsa-puszta irányába (ÉNy) vezető, ma már nem használt földutat elektromos távvezeték keresztezi. Itt, fóként az út keleti oldalán, a holtág mocsaras kanyarulata melletti kis földnyelven nagyon szórványosan apró őskori, valamint néhány égett-paticsos foltból hullámvonal köteges díszítésü kora középkori cserepeket és kevés vassalakot gyűjtöttem. Néhány csiszolt kőeszköz töredéke is előkerült. ${ }^{10}$

\section{Barcs-Puszta Barcs}

Barcstól északnyugatra, a Dráva-Coop Zrt. sertéstelepétől északra egykor emelkedett domb. Nagyobb része az 1983-óta működő homokbánya miatt már elfogyott, a maradék terület mezőgazdasági művelés alatt áll. $A$ Dráva egyik mellékága még a 19. század elején is részben körülvette a dombot, mely több kilométeres körzetben az egyetlen kiemelkedő pont volt. ${ }^{11}$ A felszínen és a bányászat során több korszak leletanyaga került elő. Itt sejthetjük a középkori-késő középkori Barcs helyét. Az 1970-es évek közepén, a domb északkeleti peremén, nagyobb területen kora középkori kerámiatöredékek voltak gyűjthetők. ${ }^{12}$ Egy ponton számos vassalak darab is előfordult, de ezekből minta akkor nem került begyűjtésre. Formájuk alapján kovácsolási salakok voltak.

\section{Barcs-Somogytarnóca, Kistarnóca}

Barcs-Somogytarnócától keletre (kb. 1 kilométer), a mai Kistarnóca-pusztától keletre lévő Kapaszkodófolyás melletti földnyelven középkori telepnyomok kerültek elő. Valószínűleg itt kereshetjük az először 1467-ben említett Kystharnocza falut. ${ }^{13}$ 14-17. századi kerámiatöredékek, fémtárgyak kerültek begyűjtésre a terepbejárás során. Egy nagyobb területen (kb.10×10 méter) a talaj sötétszürke-fekete színú volt, jelentős mennyiségű vassalak hevert a felszínen, közte gömbszelet alakú darabok is. ${ }^{14} \mathrm{~A}$ salakos részből kerámia nem került elő, így a kohászati tevékenység idejét nem tudjuk pontosan meghatározni. A gyűjtött kerámia döntő többsége azonban a 14-15. századra datálható, így feltételesen erre a korra tehető a vasfeldolgozó tevékenység ideje is (2. ábra).

\section{Péterhida-Kis-Lanka}

AKomlósd-Péterhidaközöttibekötőútközepén,azúttóldélre(kb.500méter)egy,aterepszintbőlaligkiemelkedőkisföldnyelvenkeltaés rómaikorielőzményekkelbírókoraközépkoritelepnyomokattaláltam. Hullámvonal köteges és vízszintes vonalköteges cserepeket, csont-, kő-és fémtárgyakat, vassalakot gyűjtöttema felszínen. ${ }^{15}$ Ugyanittegynégyzetes keresztmetszetű, réteges szerkezetű rúdvas darab,ún.singvasiselőkerült. Amennyiben ez is a településhez tartozó lelet, akkor az itt folyó kovácsolási tevékenység, illetve a további feldolgozásra al-

7 DMA 1041-96. Rózsás Márton jelentése. Leletanyag: DKMK

8 DMA 1041-96. Leletanyag: DKMK

9 Leletanyag: DKMK

10 DMA 960-94. Leletanyag: DKMK

11 A környező, 105 méteres átlagos szintekhez viszonyítva magasnak számított 113,3 méteres magasságával.

12 Leletanyag: DKMK

13 Magyar Nemzeti Levéltár, DL 88.444

14 DMA 328-87/19/6. Leletanyag: DKMK

15 DMA 597-89. Leletanyag: DKMK 
kalmas vasanyag előállítása bizonyítékaként is értékelhetjük. ${ }^{16} \mathrm{~A}$ lelőhely jelenleg füves rét, kaszáló (3. ábra).

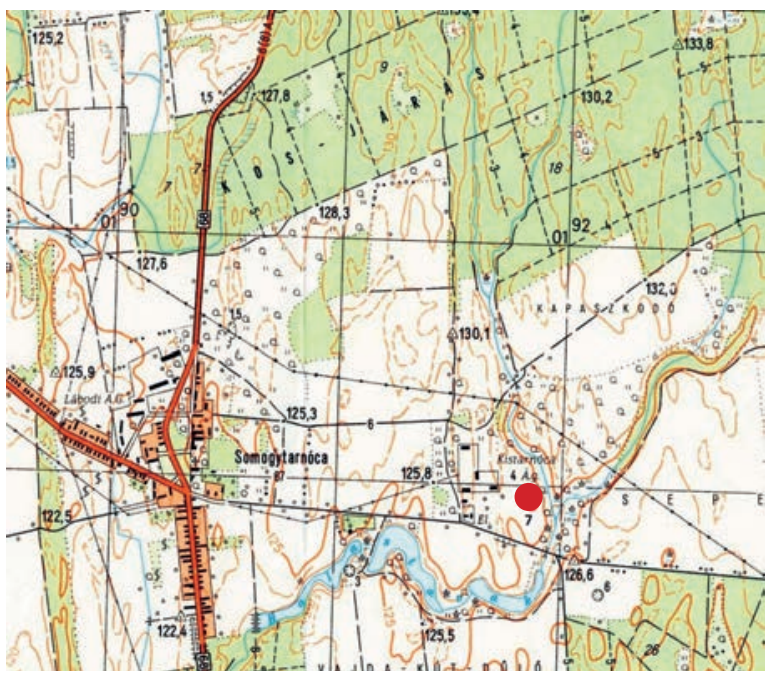

2. ábra. Somogytarnóca-Kistarnóca

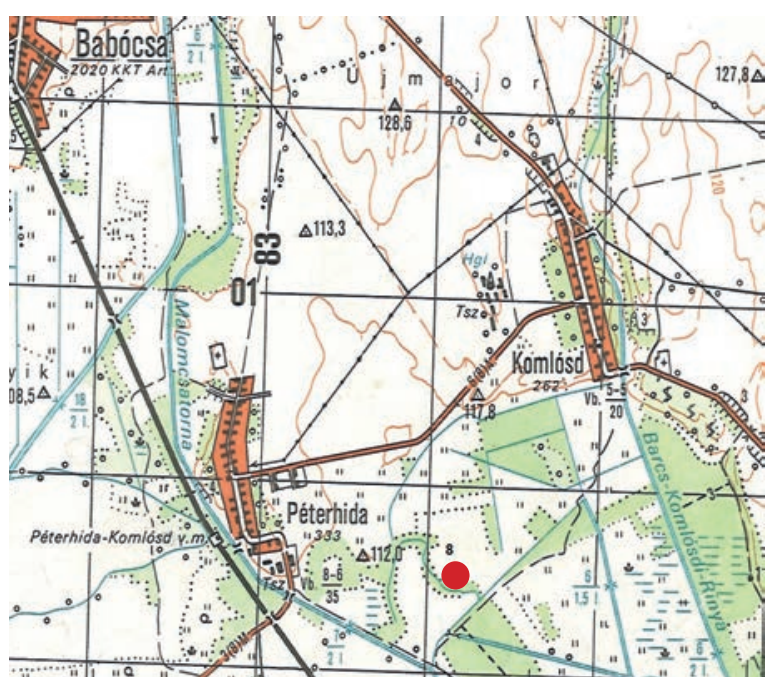

3. ábra. Péterhida-Kis-Lanka

\section{Csokonyavisonta-Nagypuszta}

A megszüntetett barcs-somogyszobi vasútvonal nyomvonalán haladva, a volt somogytarnócai állomástól északra, 3 kilométerre, a dúlőút (volt vasúti töltés) két oldalán mintegy 1 kilométer hosszan több korszakba sorolható lelőhely található. ${ }^{17}$ Ezek alapján a terület a neolitikumtól a 16. századdal bezárólag lakott volt. A lelőhely déli peremén egy kb. $5 \times 5$ méteres területen a talaj sötétszürke színú, és sok vassalak gyűjthető, faszénszemcsés közegből. Ez a folt a szántásban, illetve az eldolgozott felületen is jól kivehető. A salakos jelenség környezetéből késő középkori (14-15. századi) kerámia gyújthető, tőle északra (kb. 300 méter) viszont kevés kora középkori és Árpád-kori kerámiatöredék is előkerült (4. ábra).

\section{Drávagárdony-Temetői-dülö}

A drávagárdonyi temetőtől nyugatra lévő dombvonulat (magaspart) közepe táján, annak gerincén és déli lankáján Árpád-kori és késő középkori településnyomok, kerámiatöredékek, vassalak került elő. ${ }^{18}$ Néhány kelta vagy római kori cserép is előfordult. A salak, jellege alapján kovácsolási munka mellékterméke (5. ábra). ${ }^{19}$

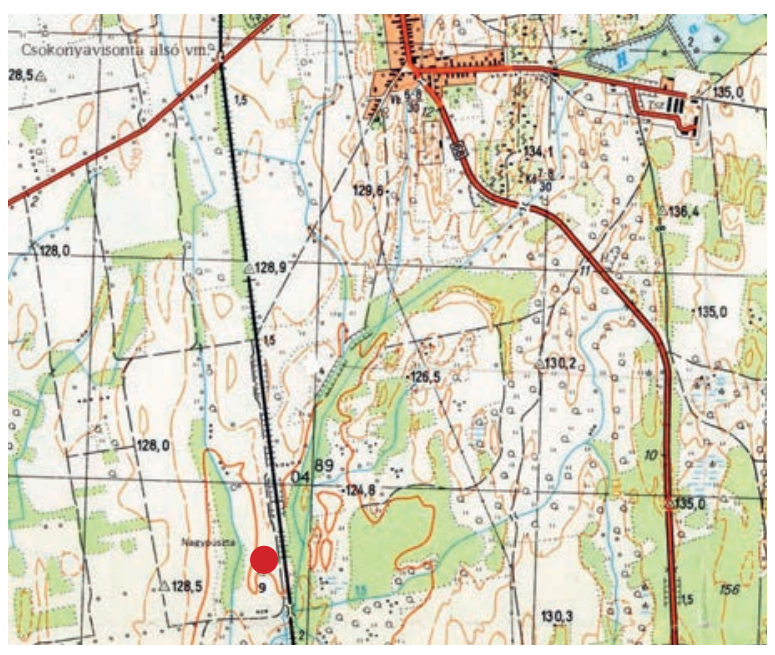

4. ábra. Csokonyavisonta-Nagypuszta

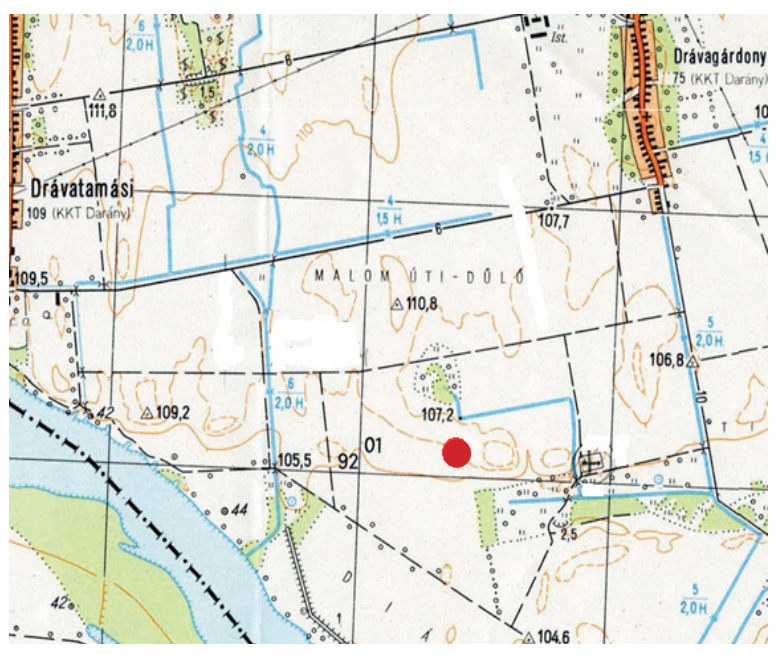

5. ábra. Drávagárdony-Temetői-dülő

16 A singvas mérete: $13 \times 2,8 \times 1.8 \mathrm{~cm}$; BognÁr 2016, 225 és 10. ábra

17 DMA 544-88. Rózsás Márton jelentése. Leletanyag: DKMK

18 DMA 679-90. Rózsás Márton jelentése. Leletanyag: DKMK

19 То́тн 2010. 


\section{Összegzés}

„A somogyi gyepvasérc telepek a kora középkorban a területen folyó vaskohászat ércbázisául szolgáltak."20 Egyes, Rinya menti gyepvasérc előfordulások már eddig is ismertek voltak, azonban a csatlakozó kisebb vízfolyások, patakok - így a Györgyös-patak - térségében is okkal feltételezhető nyersanyag lelőhelyekre nem találtam utalást. ${ }^{21}$ Somogytarnóca környéki bejárásaim során több esetben észleltem vélhetőleg gyepvasérc (mocsárérc) előfordulására utaló nyomokat. Megfigyeléseket a Györgyös-patak medrének kimetszése (partoldalának rézsűzése), illetve a patakot keresztező gázvezeték árkának kiásása során tehettem. Ezek szerint a patak néhol 30-50 centiméter vastag, mocsári üledékkel fedett szürke-iszapos talajba vágódott be, ez a partoldalak metszetében jól megfigyelhető volt. A gyepvasérc/mocsárérc gumók ebbe az üledékbe ágyazódva fordultak elő, majd innét a víz által kimosva a meder alján is gyűjthetők voltak. Esetleges koncentrálódásukat, mennyiségüket nem tudtam megfigyelni. Nagy valószínűséggel feltételezhetjük, hogy a tárgyalt kora középkori, de talán a későbbre (Árpád-kor) datálható lelőhelyek kohói is ezt a helyben található, vagy a közelben gyűjtött nyersanyagot használhatták fel. ${ }^{22}$ Természetesen erre csak a lelőhelyeken gyűjtött salakminták elemzése adhatna választ.

Az olvasztás technológiáját illetően a kísérleti régészet által rekonstruált bucakemencékkel folytatott próbaolvasztásokra tudunk hagyatkozni. Mindezek ellenére úgy véljük, hogy a kohók felszínre épített, múhelygödör nélküli, jellegzetesen pannóniai, avar, vagy nemeskéri típusúak lehettek. ${ }^{23}$ Ezt nemcsak a múhelygödrök hiánya látszik alátámasztani, hanem a lelőhelyek elhelyezkedése is. ${ }^{24}$ Általánosságban elmondható, hogy környékünkön a kora középkori, vasolvasztással kapcsolatba hozható lelöhelyek szinte kivétel nélkül a jelenlegi terepszintből alig kiemelkedő, egykori mocsári szigeteken, szárazulatokon, vízpartokon találhatók. ${ }^{25} \mathrm{~A}$ kohók/ műhelyek használata idején a holtágak, és a ma időszakos kis folyások élő vizek voltak (a 19. század közepéig), így a talajvíz a mai szintnél is jóval magasabb lehetett. Emiatt mühelygödrök kialakítására a legtöbb helyen valószínúleg nem lett volna lehetőség. Egyetlen kivétel a magaslatra települt Puszta Barcs, amely a környező kisebb telepek között talán valamiféle központnak számíthatott.

A lelőhelyek felszíni kerámiaanyaga nagyon hasonló, azonban a vassalak mennyisége lelőhelyenként változó. Egyes lelőhelyeken ahhoz kevés, hogy nagyobb volumenü, vagy hosszan müködő kohászatra gondoljunk, viszont ahhoz sok, hogy véletlenszerủ odakerülést feltételezzünk. A salak összetétele azt mutatja, hogy e kis telepek egy részén kohászati és kovácsolási tevékenység is folyt. Valószínúnek látszik, hogy egyegy mühely/telep olykor áttelepülésre lehetett kényszerülve, talán a vízszint időnkénti változása/emelkedése, vagy a közelben található érclelőhely kimerülése miatt. Az sem kizárt, hogy a kohászati tevékenységet eleve igyekeztek a lakótértől távolabb folytatni, vagy több helyen egy időben folyt a munka. Esetünkben talán nem hozható a telepek elhelyezkedésével közvetlenül kapcsolatba, de említést érdemel, hogy az ismertetett 6 barcsi lelőhely egy kisebb, római kori telep, illetve a részben rátelepült középkori faluhely közelében található. A késő avar kori, illetve a 9. századi kohók korábbi római kori telepek, villák helyére vagy közelébe való települését a Dunántúlon, több helyen megfigyelték. ${ }^{26}$

Néhány lelőhely esetében bizonytalanságra adhat okot a funkció (kohó vagy kovácsmühely? mindkettő?) egyértelmű meghatározása, mivel vasolvasztásra utaló direkt leletek (fúvók, mellfalazat, kohódarabok, folyósalak stb.) a felszínen nem voltak. Ami mégis a kovácsolás mellett szól, az a salakdarabok szerkezete és alakja.

A kovácssalak darabok ugyanis többnyire jellegzetesen gömbszelet alakúak, szerkezetük olykor szivacsos, a kohósalak darabokon viszont láthatóak a lecsapolás során keletkezett folyásnyomok („folyósalak"). Jelenlegi ismereteink alapján úgy tűnik, hogy Barcs-Puszta Barcs, Somogytarnóca-Kistarnóca, CsokonyavisontaNagypuszta és Drávagárdony-Temetői-dűlő lelőhelyeken elsősorban kovácsolási munka (kovácsműhely) folyhatott, mivel ezeken a helyeken folyósalakot nem, vagy elenyésző mennyiségben találtunk. ${ }^{27}$ A csokonyavisontai lelőhelyen a kora középkori kerámiát a vassalakos helytől viszonylag távolabb gyűjtöttem,

20 GÖMÖRI 2000a, 373

21 GÖMÖRI 2000a, 264; ThIELE 2009. (Somogyszob); www.geomania.hu/lelohely.php? lelohely=670 (Rinya ártéri gyepvasérc telepei, Babócsa, Somogy megye. Gulyás Zoltán nyomán) - Ez a megállapítás a Dráva mentére is vonatkoztatható.

22 То́тн 2010.

23 Közös jellemzőjük a mellfalazattal egybeépített fúvók, ilyenek kerültek elő Tarcsa-puszta, Kereszti-dűlő lelőhelyen. GömöRı $2000 a, 225$.

24 A Tarcsa-puszta, Kereszti-dűlő lelőhelyen folytatott szondázás során sem bukkantunk műhelygödör nyomára, a szelvény többszöri bővítése ellenére sem.

25 GÖMÖRI 2000a, 268. Barcs környékén az egykor vízjárta területek bejárása is fontos lenne, mert - mint ezt jelen munkám készítése során is tapasztaltam - az eddig lakatlannak vélt területeken is fontos lelőhelyek lehetnek.

26 GömöRı 2000a, 223. A római kori és a középkori faluhely területén is gyűjtöttem vassalakot, de ezek hovatartozását a lelőhelyek átfedése miatt nem lehetett meghatározni. Jellegük alapján kovácssalakok.

27 Gömörı 2000a, 28. Az sem lehetetlen, hogy a kohók (ha voltak itt ilyenek) távolabb, a ma már fedett, nem megfigyelhető területeken helyezkedtek el. 
ami több kérdést is felvethet: összetartozik-e a két jelenség, azaz a vasas tevékenység kapcsolódott-e a feltételezett településhez, esetleg a mühelyt szándékosan helyezték távol a lakókörnyezettől. Mivel a hullámvonal köteges és vízszintes vonalköteges cserepek mellett kora Árpád-kori, bekarcolt hullámvonallal díszített kerámiatöredékek, valamint késő középkori kerámiák is előfordultak, a műhely működési idejének meghatározása - ásatás nélkül - aligha lehetséges. Ebbe a körbe kell sorolnunk a drávagárdonyi lelőhelyet is, mivel a közelében római kori és középkori leletek egyaránt előfordulnak. Két lelőhely ma már egyáltalán nem kutatható. ${ }^{28}$

A tárgyalt kora középkori lelőhelyek kormeghatározásánál - ásatási megfigyelések hiányában - csak a terepbejárások során gyűjtött felszíni szórványos anyagra, elsősorban a kerámiatöredékekre támaszkodhatunk. Az egyéb leletek száma elenyésző, vaskés, vas zablapálca, orsógomb, csontárak és több fenőkő került elő. Nagyobb mennyiségú kerámiát két helyen találtunk, Péterhida-Kis-Lanka és Barcs-Puszta Barcs lelőhelyeken, de a többi lelőhely anyagában is van értékelhető kerámiaanyag. Ezek többsége lassú korongon készült, színük a narancssárgától a sötétbarnáig szóródik, anyaguk jellemzően sok finom, vagy durvább szemű homokkal kevert. Gyakori, hogy a kerámia színe kívül és belül más-más színű, általában kívül barnás, belül néha fekete. Díszítésük befésült hullámvonalkötegek, vagy párhuzamos vonalkötegek, olykor a kettő kombinációja. Fogaskerekes benyomás (rádlizás), vagy csigavonal, esetleg széles közökben bekarcolt párhuzamos vonal egyáltalán nem fordul elő. A peremek egységes képet mutatnak, szinte valamennyi egyszerü, tagolatlan, keskeny, ívelten, vagy enyhe szögben kihajló. Az ismertetett lelőhelyek közül 7 lelőhelyen néhány fésűs hullámvonalas belső peremdíszítés is előfordult. Talptöredék nagyon kevés került elő, ezeken homok alászórás és néha korongcsap lenyomata látszik. Kézi formálású kerámiát nem találtam.

Ezek alapján, és - mint a bevezetőben írtam - az összehasonlító ásatási anyag segítségével a szóban forgó kora középkori lelőhelyek és leletek korát a késő avar kort követő időszakra, a 9-10. századra keltezhetjük. ${ }^{29}$

A középkor további szakaszaiban a kis kohók termelése a 14-15. századig, a bányászott vasérccel, nagyobb hatásfokkal dolgozó vashuták és vashámorok elterjedéséig folytatódhatott. Ez időtől a kovácsműhelyek kereskedelmi úton beszerzett, vagy újra felhasznált vasanyagot dolgozhattak fel, múködésük a falvak életével szinkronban, folyamatos lehetett.

\section{Medieval iron smelting at Barcs and in its broader area}

\section{MÁRTON RÓZSÁS}

The area along the County Somogy section of the River Drava was an archaeological blank spot until recent decades. Several previously unknown archaeological sites from the Neolithic to the Early Modern Age were identified during the field surveys conducted by the author since the 1970s. Described and discussed here are a few sites associated with medieval iron smelting dating from the ninth to the fifteenth century. 

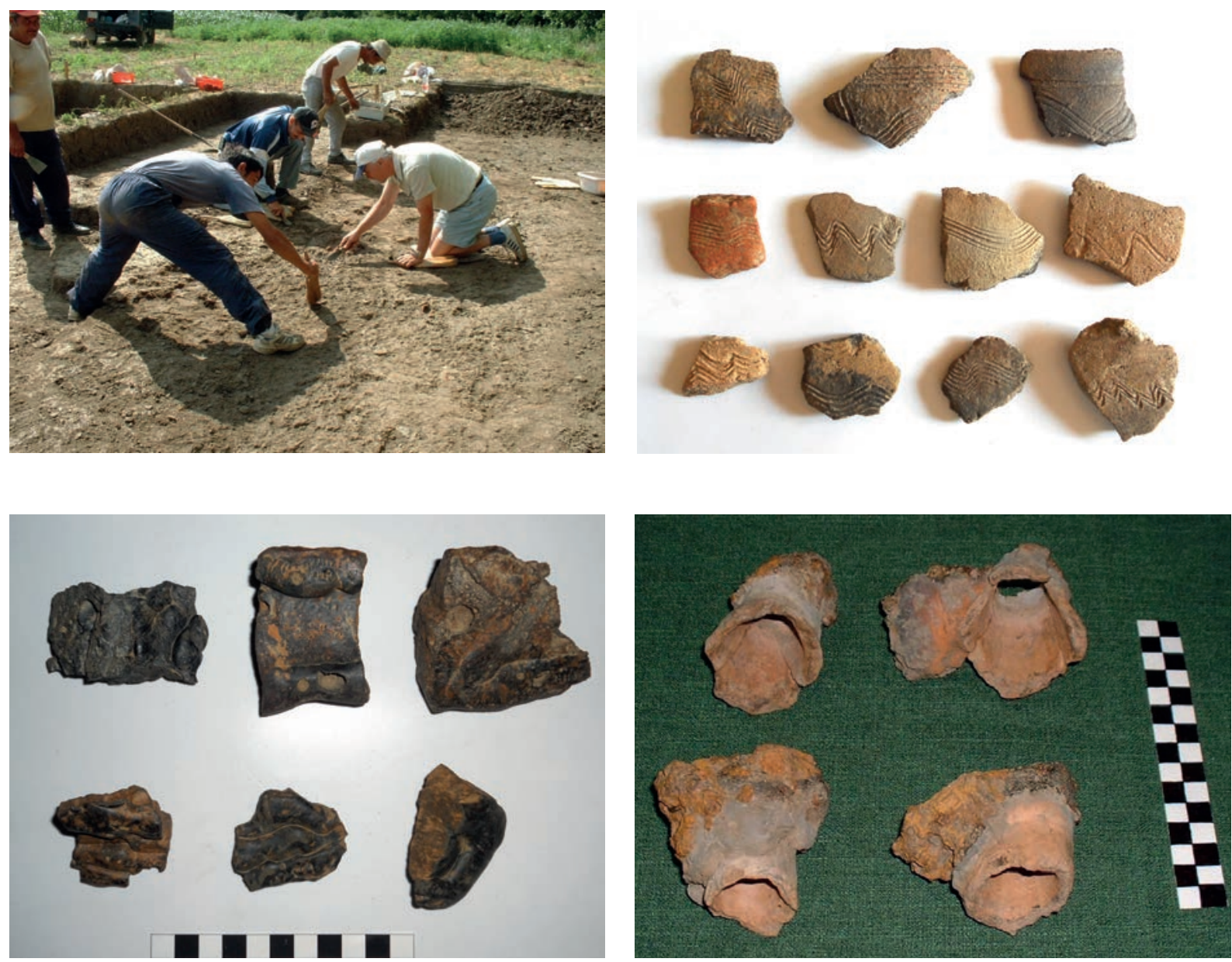

6-9. ábra. Barcs-Tarcsa-puszta, Kereszti-dülő

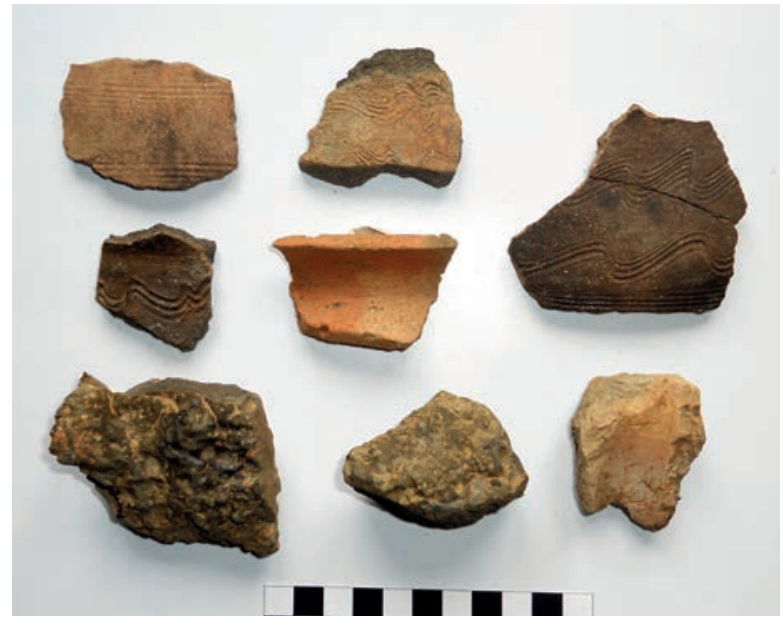

10. ábra. Barcs-Perdély

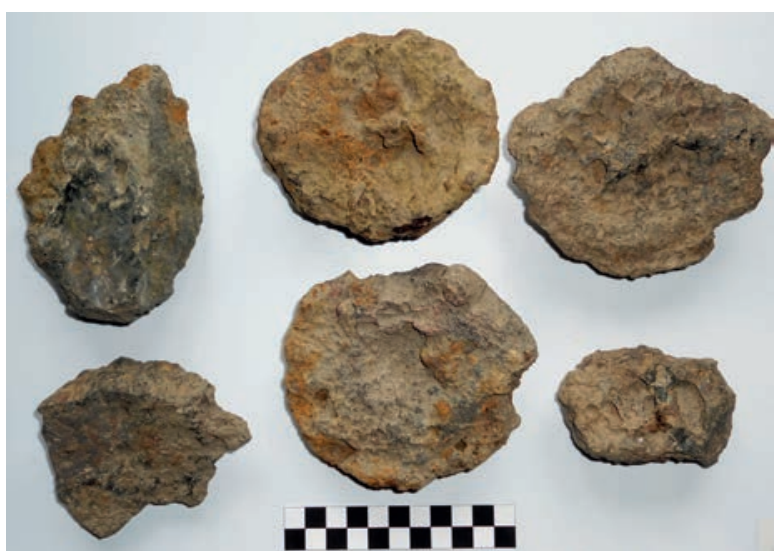

11. ábra. Somogytarnóca-Kistarnóca 

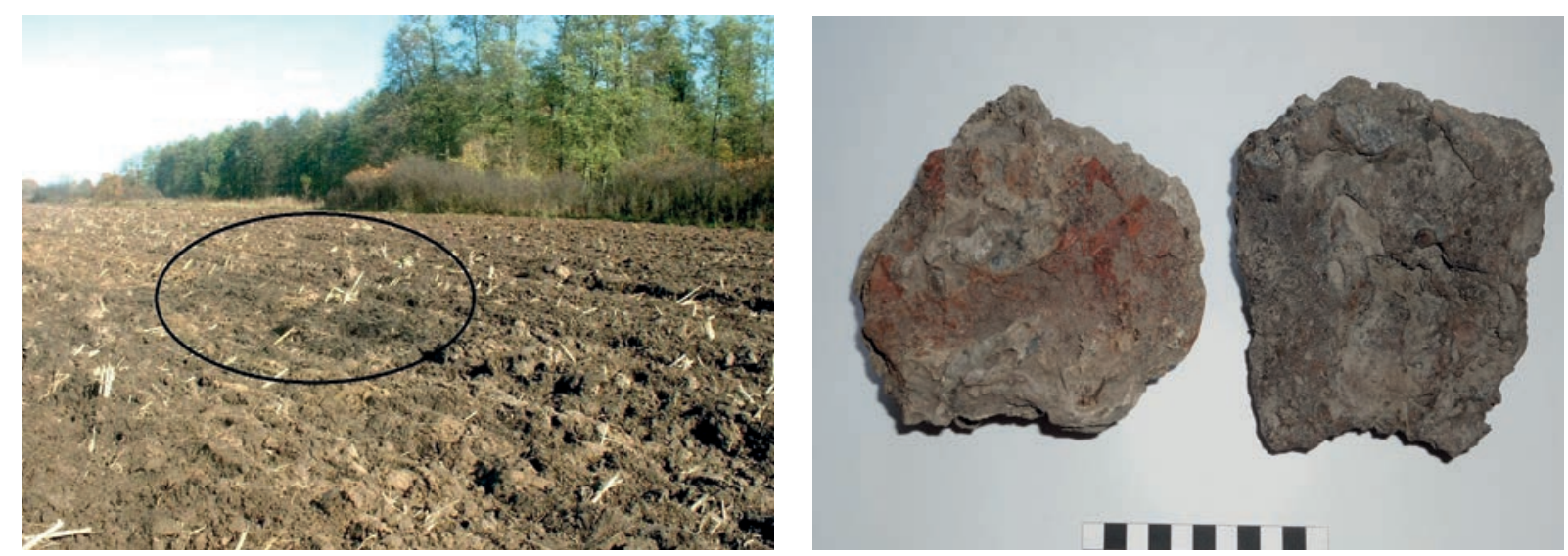

12-13. ábra. Csokonyavisonta-Nagypuszta

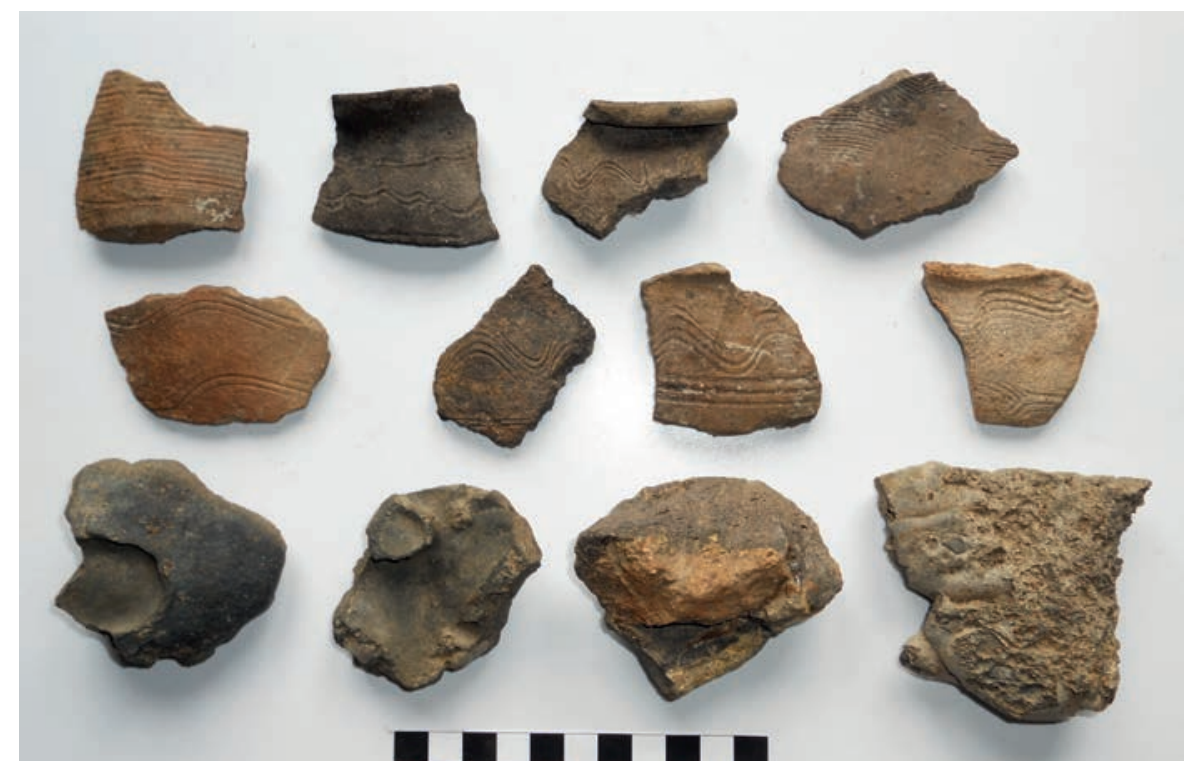

14. ábra. Péterhida-Kis-Lanka

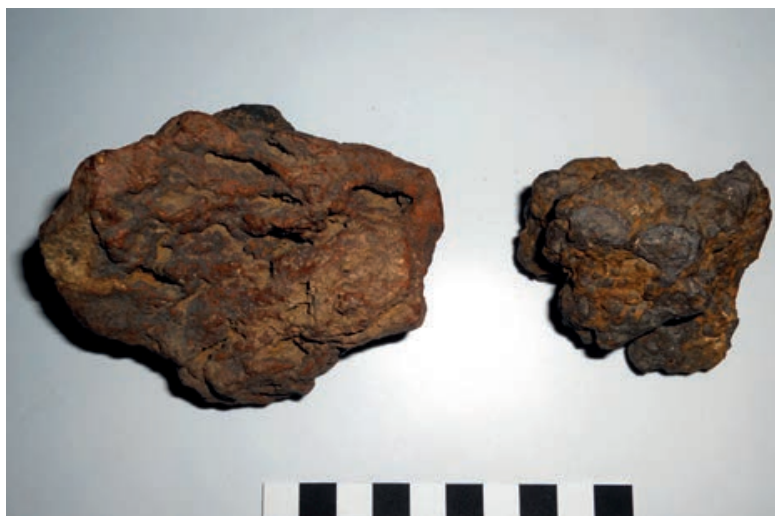

15. ábra. Mocsárérc. Somogytarnóca, Drávatamási

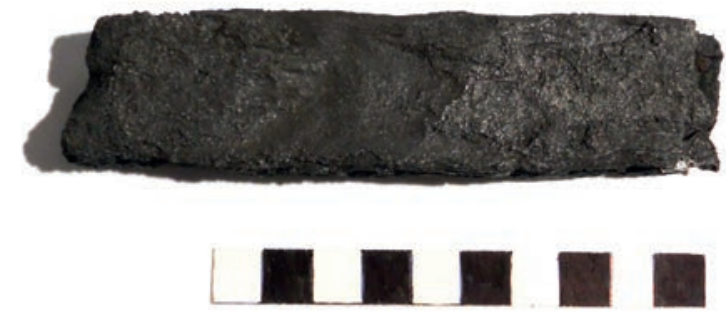

16. ábra. Singvas. Péterhida 


\section{Irodalom}

BoGNÁR 2016 Bognár Katalin Boglárka: Vaseszközlelet Balatonőszöd Árpád-kori településéről. A Kaposvári Rippl-Rónai Múzeum Közleményei 4. 221-234.

FEKETE et AL. 2005 Fekete Csanád - Honti Szilvia - Horváth Friderika - Jankovich-Bésán Dénes - Korom Anita - Költő László: Terepbejárások Somogy megyében 1999-2004. In: Kisfaludi Júlia (szerk.): Régészeti Kutatások Magyarországon 2004. Budapest, 2005. 91-120.

GöMÖRI 2000a Gömöri János: Az avar kori és Árpád-kori vaskohászat régészeti emlékei Pannóniában. Sopron, 2000.

Gömörı 2000b Gömöri János: Az avar kori és X-XI. századi vaskohászat régészeti emlékei Somogy megyében. Somogyi Múzeumok Közleményei 14. 163-218.

HECKENAST ET AL. 1968 Heckenast Gusztáv - Nováki Gyula - Vastagh Gábor - Zoltay Endre: A magyarországi vaskohászat története a korai középkorban. Budapest, 1968.

KAnÁsz 2005 Kanász Tamás: A bucavas gyártására irányuló kísérletek eredményeinek bemutatása. TDK dolgozat. Budapest, 2005.

KovÁCS ET AL. 2014 Kovács Gyöngyi - Bartosiewicz László - Éder Katalin - Gál Erika - Miklós Zsuzsa - Rózsás Márton - Tóth János Attila - Zatykó Csilla: Medieval and Ottoman Period (14 $4^{\text {th }}-17^{\text {th }}$ C.) archaeology in the Drava river region, Hungary. Acta Archaeologica Hungaricae 65. 155-168.

MAGYAR 2000 Magyar Kálmán: A bodrog-alsó-bűi nemzetségi központ régészeti kutatása (1979-1999). Somogyi Múzeumok Közleményei 14. 115-161.

NÉMETH 2010 Németh Péter Gergely: A Dráva-mente felfedezése. Somogyi Múzeumok Közleményei 19. 44.

THIELE 2009 Thiele Ádám: A bucavas koraközépkori előállitásának korhű gyártástechnológiája a korszerü anyagtudomány tükrében. TDK dolgozat. Kézirat, Budapest, 2009.

TóтH 2010 Tóth János Attila: Lelöhelyek a magasparton. 2010. 05.13. http://buvarregesz.blog.hu/page/7?_ts=201106190151 23\&token=5ed293a9ae91 cfael15fe4fc1498a9e28 (letöltés: 2017. november 04.) 
